Milaim Sadiku, orcid.org/0000-0002-9387-8124, Mensur Kelmendi, orcid.org/0000-0001-7002-2406, Sadija Kadriu, orcid.org/0000-0001-6223-3342
Faculty of Food Technology, University "Isa Boletini”, Mitrovica, the Republic of Kosovo, e-mail: milaim.sadiku@umib.net

\title{
ASSESSMENT OF HEAVY METAL POLLUTION OF SEDIMENTATION IN THE SITNICA RIVER BASED ON POLLUTION INDICATORS
}

Purpose. To show the impact of the Mitrovica Industrial Park landfill on the Sitnica River pollution through sediment analysis. For this purpose, to assess the level of pollution and ecological impact pollution indicators were used: geo-accumulation index, contamination factor, pollution rate, and modified pollution rate, enrichment factor, potential ecological risk index, pollution load index.

Methodology. The ISO 5667-15:2009 standard method was used for sediment sampling. At the same time, the standard method ISO 11885:2007 was used for the determination of selected elements by inductively coupled plasma optical emission spectrometry (ICP-OES). Analytical methods were used to calculate pollution indicators.

Findings. From the obtained results it can be concluded that the concentrations of heavy metals in the sediment of the river Sitnica have exceeded the allowed values. According to our estimates, the impact of the landfill on the pollution of the river Sitnica is undeniable.

Originality. The paper provides new data on the impact of the MIP landfill on the pollution of the Sitnica River and, respectively, on its ecological status. The findings are based on the obtained results from the analyzed samples and their comparison with the allowed values for sediments. Pollution also affects the food chain as the water of this river is used for irrigation of gardens; moreover, fish are harvested in this river.

Practical value. It should be taken into consideration that the content and the problematic delved in this paper are vivid and represent a prominent interest to those who deal with this issue.

Keywords: heavy metals, pollution indicators, Sitnica River, sediment contamination

Introduction. Industrial waste generated by the former mining, chemical metallurgical plant "Trepça", respectively its mining, metallurgical and chemical units are a source of environmental pollution with heavy metals in Mitrovica and the surrounding area. Today except for the mine, other units from the former factory "Trepça" have remained as relics from the past. It was a huge industry operated under socialist values, where environmental and public health issues were of limited concern in relation to the objective of achieving economic growth. The tailing, which is a waste product from the production process, is the main environmental problem related to Trepca. The tailings material at Trepca can thus be spread to the environment by the wind or through erosion [1,2].

However, chemical reactions may also spread the tailings material and release the heavy metals present in it to the environment $[3,4]$. For instance when lead enters the environment, it does not break down, but its chemical structure is changed by sunlight, air and water [5]. When it is released to the air, it may travel long distances before settling to the ground, and when lead falls onto the soil, it usually sticks to the soil particles. The movement of lead from the soil into the ground water will depend on the type of lead compound and the characteristics of the soil. Tailings of industrial waste in the Mitrovica Industrial Park (MIP) comprise an area of 34.62 hectares.

The total measure of these industrial wastes is about 1.52 million tons. The tailing consists of four types of industrial wastes, pyrites and pyrrhotite $500000 \mathrm{t}$, phosphogypsum $400000 \mathrm{t}$, jarosite 120000 and the remainder of the process of so-called neutral leaching of zinc also known as EIMCO $500000 \mathrm{t}$. The tailing is perceived from the Ministry of Environment and Spatial Planning of Kosovo as "The Hot Spot" area. In Fig. 1. the view of industrial tailing in MIP is depicted [6].

The polluted rivers with heavy metals are carriers of these metals; sediments of these rivers containing heavy metals are a source of secondary pollution, and also indicate the level of pollution $[7,8]$. Therefore there is a need for sediment quality indicators to assess the risk of heavy metal contamination in

(C) Milaim Sadiku, Mensur Kelmendi, Sadija Kadriu, 2021 aquatic environments. Such indicators are: contamination factor $(\mathrm{CF})$ [9], contamination degree (Cd) [10], pollution load index (PLI), the geo-accumulation index (Igeo) [11, 12] and the enrichment factor (EF) [13, 14].

Materials and methods. To determine the extent of the impact of the MIP landfill on the pollution of the Sitnica River with heavy metals, sediments in the river were analyzed. Sediment samples were taken at specific locations along the river flow. The river flows along the landfill. All samples are taken on the right side of the river flow. The first sample was taken $300 \mathrm{~m}$ upstream the Sitnica River, south of the MIP area. The second sample, (S-2) was taken $235 \mathrm{~m}$ below the river at the place where the river Trepça flows into the river Sitnica. Samples three (S3), four (S4), five (S5), and six (S6) were taken in the river flows along the landfill. When the samples were taken in the river, there were algae, waste, and at the same time, there was a smell of sewage. Geographical coordinates of sampling are given in Table 1.

Sampling and analysis were done based on the standards ISO 5667-15:2009 and ISO 11885:2007. The obtained results are presented in Table 2. Fig. 2 presents the view between the tailing and the Sitnica River.

Heavy metals indices. Geo-accumulation index. Geo-accumulation index is a parameter used to determine the level of pollution with heavy metals in the soil and aquatic sediments $[11,12]$. The formula for the geo-index is given by Muller (1979), [15]

$$
I_{\text {geo }}=\log _{2} \frac{C_{n}}{1.5 \cdot B_{n}}
$$

where $C_{n}$ is the measured concentration of metal $\mathrm{n}$ in the sediment and $B_{n}$ is the geochemical background value of element $\mathrm{n}$ in the background sample [15-17]. The factor 1.5 is introduced to minimize the possible variations in the background values which may be attributed to lithogenic effects [18].

The background data used is from Turekian and Wedepohl (1961) [19]. The degree of heavy metal contamination in lake sediments was determined based on the $I_{g e o}$ classes Muller (1979) [11]. Table 2 provides Classes of geo-accumulation index and a description of sediment quality. 


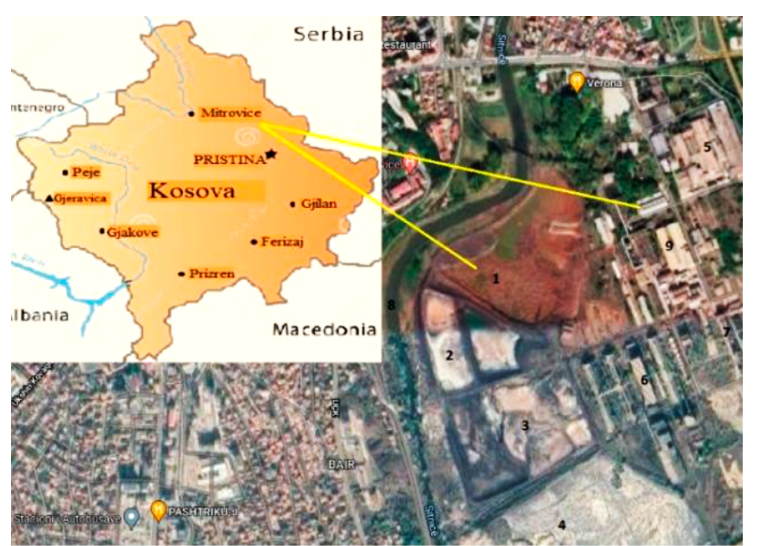

Fig. 1. Landfill and MIP view:

1 - EIMCO sediment; 2 - Pyrite and pyrrhotite; 3 - Jarosite; 4 - Phosphogypsum; 5 - Battery Industry; 6 - Zinc Metallurgy; 7 - Chemical Industry; 8 - River Sitnica

Table 1

Geographical coordinates of the sampling site

\begin{tabular}{|l|c|c|}
\hline & Latitude & Longitude \\
\hline $\mathrm{S} 1$ & $42^{\circ} 52^{\prime} 33.34^{\prime \prime} \mathrm{N}$ & $20^{\circ} 52^{\prime} 39.53^{\prime \prime} \mathrm{N}$ \\
\hline $\mathrm{S} 2$ & $42^{\circ} 52^{\prime} 40.55^{\prime \prime} \mathrm{N}$ & $20^{\circ} 52^{\prime} 29.88^{\prime \prime} \mathrm{N}$ \\
\hline $\mathrm{S} 3$ & $42^{\circ} 52^{\prime} 52.35^{\prime \prime} \mathrm{N}$ & $20^{\circ} 52^{\prime} 26.80^{\prime \prime} \mathrm{N}$ \\
\hline $\mathrm{S} 4$ & $42^{\circ} 53^{\prime} 6.96^{\prime \prime} \mathrm{N}$ & $20^{\circ} 52^{\prime} 30.53^{\prime \prime} \mathrm{N}$ \\
\hline $\mathrm{S} 5$ & $42^{\circ} 53^{\prime} 12.80^{\prime \prime} \mathrm{N}$ & $20^{\circ} 52^{\prime} 39.89^{\prime \prime} \mathrm{N}$ \\
\hline S6 & $42^{\circ} 53^{\prime} 27.62^{\prime \prime} \mathrm{N}$ & $20^{\circ} 52^{\prime} 38.87^{\prime \prime} \mathrm{N}$ \\
\hline
\end{tabular}

Table 2

Classes of geo-accumulation index and description of sediment quality, Muller

\begin{tabular}{|c|c|l|}
\hline Class & Index Value & \multicolumn{1}{|c|}{ Description of sediment quality } \\
\hline 0 & $I_{g e o} \leq 0$ & Uncontaminated \\
\hline 1 & $0<I_{g e o}<1$ & Uncontaminated to moderately contaminated \\
\hline 2 & $1<I_{g e o}<2$ & Moderately contaminated \\
\hline 3 & $2<I_{g e o}<3$ & Moderately to strongly contaminated \\
\hline 4 & $3<I_{g e o}<4$ & Strongly contaminated \\
\hline 5 & $4<I_{g e o}<5$ & Strongly to extremely contaminated \\
\hline 6 & $I_{g e o}>5$ & Extremely contaminated \\
\hline
\end{tabular}

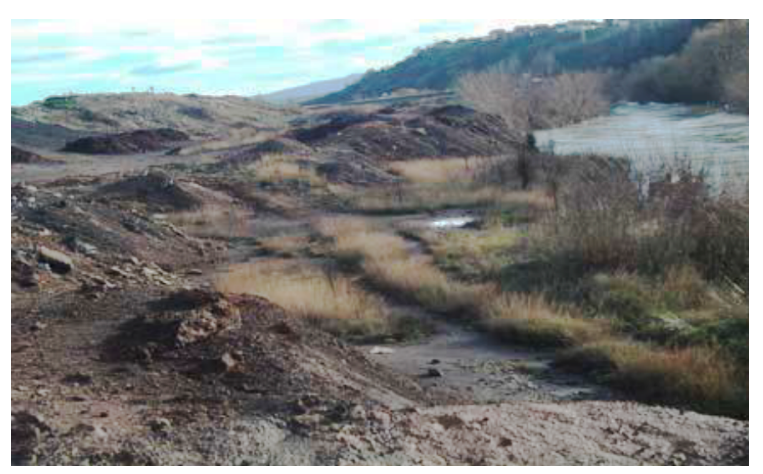

Fig. 2. A view between the tailing and the Sitnica River

The Contamination Factor. The Contamination Factor represents the ratio between the average concentrations of the toxic substrate in sediment, the standard preindustrial reference value for the substance [20].

$$
C_{f}^{i}=\frac{C_{\text {sample }}^{i}}{C_{\text {refernce }}^{i}},
$$

where $C_{\text {sample }}^{i}$ is the value gained concentration of a pollutant in samples in the contaminated site; $C_{\text {reference }}^{i}$ is the pre-industrial concentration of elements using the Earth's crust as a reference by Turekian and Wedepohl (1961) [21].

According to the contamination factor $\left(C_{f}^{i}\right)$, single elements, $C_{f}^{i}$ f is classified in four levels. Classes of contamination factor are given in Table 3.

Degree of contamination and modified degree of contamination. Hakanson proposed that the numeric sum of the eight specific contamination factors (As, $\mathrm{Cd}, \mathrm{Cu}, \mathrm{Cr}, \mathrm{Hg}, \mathrm{Pb}, \mathrm{Zn}$ and organic pollutant $\mathrm{PCB}$ ) expressed the overall degree of sediment contamination $\left(C_{d}\right)$. This amount is given by the formula

$$
C_{d}=\sum_{i=1}^{8} C_{f}^{i}
$$

Since Hakanson's (1980), the degree of contamination was limited, Abraham (2005) modified this formula.

The generalized modified formula of contamination degree, $\left(m C_{d}\right)$, is defined as the ratio of the sum of the Contamination Factor $\left(C_{f}^{i}\right)$ to the number of analyzed contaminants.

$$
m C_{d}=\frac{\sum_{i=1}^{n} C_{f}^{i}}{n},
$$

where $n$ is the number of analyzed elements; $i$ is an element (or pollutant); $C_{f}^{i}$ is the contamination factor.

The description of the modified degree of contamination $(\mathrm{mCd})$ for sediments. Classes of the degree of contamination are given in Table 4.

Enrichment factor (EF). The enrichment factor is the most important indicator of anthropogenic impact on sediment [13, 14]. The enrichment factor (EF) is calculated based on the standardization of a measured element in samples against a reference element. The frequent mostly used elements are Al, $\mathrm{Fe}, \mathrm{Mn}, \mathrm{Sc}, \mathrm{Ti}$ [23]. The enrichment factor was calculated using the following equation

$$
E F=\frac{\left(C_{x} / C_{r e f}\right)_{\text {sample }}}{\left(C_{x} / C_{\text {ref }}\right)_{\text {background }}},
$$

Table 3

Classes of contamination factor [22]

\begin{tabular}{|c|l|}
\hline$C_{f}^{i}<1$ & Low contamination factor \\
\hline $1 \leq C_{f}^{i}<3$ & Moderate contamination factor \\
\hline $3 \leq C_{f}^{i}<6$ & Considerable contamination factor \\
\hline$C_{f}^{i} \geq 6$ & Very high contamination factor \\
\hline
\end{tabular}

Table 4

Classes of degree of contamination

\begin{tabular}{|c|l|}
\hline$m C_{d}<1.5$ & Nil to very low degree of contamination \\
\hline $1.5 \leq m C_{d}<2$ & Low degree of contamination \\
\hline $2 \leq m C_{d}<4$ & Moderate degree of contamination \\
\hline $4 \leq m C_{d}<8$ & High degree of contamination \\
\hline $8 \leq m C_{d}<16$ & Very high degree of contamination \\
\hline $16 \leq m C_{d}<32$ & Extremely high degree of contamination \\
\hline$m C_{d} \geq 32$ & Ultra high degree of contamination \\
\hline
\end{tabular}


where $C_{x}$ is the concentration of the interest; $C_{r e f}$ is the concentration of the proxy normalized element. In this study, aluminum $(\mathrm{Al})$ was used as reference.

Me represents the metal concentration in the sediment and in the background. The background levels of As $\left(13 \mathrm{mg} \cdot \mathrm{kg}^{-1}\right)$, $\mathrm{Cd}\left(0.3 \mathrm{mg} \cdot \mathrm{kg}^{-1}\right)$, Co $\left(19 \mathrm{mg} \cdot \mathrm{kg}^{-1}\right), \mathrm{Cr}\left(90 \mathrm{mg} \cdot \mathrm{kg}^{-1}\right), \mathrm{Cu}$ $\left(45 \mathrm{mg} \cdot \mathrm{kg}^{-1}\right), \mathrm{Ni}\left(68 \mathrm{mg} \cdot \mathrm{kg}^{-1}\right), \mathrm{Pb}\left(20 \mathrm{mg} \cdot \mathrm{kg}^{-1}\right), \mathrm{Zn}(95 \mathrm{mg} \times$ $\left.\times \mathrm{kg}^{-1}\right), \mathrm{Al}\left(80000 \mathrm{mg} \cdot \mathrm{kg}^{-1}\right)$, and reported for sedimentary rocks were considered as the background values of these elements, Turekian and Wedepohl (1961) [24].

Birch (2003) divided contamination into different categories based on $E F$ values. $E F<1$ demonstrates "no enrichment", $E F<3$ is "minor enrichment", $E F=3-5$ is "moderate enrichment", $E F=5-10$ is "moderately severe enrichment", $E F=$ $=10-25$ is "severe enrichment", $E F=25-50$ is "very severe enrichment" and $E F>50$ is "extremely severe enrichment" [20].

The potential ecological risk factor. The potential ecological risk factor for any given substance is defined as product of the toxic-response factor and contamination factor. The equation for calculating is proposed by Hakanson (1980) [25, 26], as the following

$$
E_{r}^{i}=T_{r}^{i} \cdot C_{f}^{i}
$$

where $C_{f}^{i}$ is the contamination factor.

Hakanson (1980) defined a toxic-response factor for a given substance and demonstrated this value for $\mathrm{Hg}(40)$, As (10), $\mathrm{Cu}(5), \mathrm{Pb}(5), \mathrm{Ni}(5), \mathrm{Cr}(2), \mathrm{Zn}$ (1), Mn (1) [27, 28].

The potential ecological risk index (RI). Formulated by Hakanson in 1980, the potential ecological risk index is the sum of potential ecological risk factors. The potential ecological risk index is calculated as the equation

$$
R I=\sum_{i=1}^{n} E_{r}^{i}
$$

where $E_{r}^{i}$ is potential ecological risk factor; $n$ is the number of analyzed heavy metals.

The potential ecological risk index is used to determine the amount of ecological risk level of heavy metals in sediment $[29,30]$
Pollution Load Index (PLI). Pollution Load Index (PLI) is calculated using the equation of Tomilnson, et al. (1980), and represents the nth root of $\mathrm{n}$ number multiplying the factors $\left(C_{f}^{i}\right)$ values) together [10]. PLI is calculated by the following formula

$$
P L I=\sqrt[n]{C_{f 1}^{i} \cdot C_{f 2}^{i} \cdot C_{f 3}^{i}, \ldots, \cdot C_{f n}^{i}},
$$

where $C_{f}^{i}$ is the contamination factor, and $\mathrm{n}$ is the metals of number. The index as presented provides a simple, comparative means for assessing estuarine quality: a value of zero indicates perfection, a value of one indicates that only baseline levels of pollutants are present, and values above one would indicate progressive deterioration of estuarine quality [19]. Levels for Ecological risk and risk index (RI) classification are given in Table 5.

Results and discussion. Table 6 denotes the numerical values of metals investigated in sediments at different sampling sites. To assess heavy metals concentrations in sediment, $\mathrm{Nu}$ merical Sediment Quality Guidelines are applied.

These published SQGs were then used to develop two consensus-based SQGs for each contaminant, including a threshold effect concentration (TEC; below which adverse effects are not expected to occur) and a probable effect concentration (PEC; above which adverse effects are expected to occur more often than not). Thus, sediment samples are non-toxic if the measured concentrations of a chemical substance were lower than the corresponding TEC. Conversely, samples are toxic if their concentrations exceed the corresponding PEC values.

Numerical values for TEC and PEC are given in Table 6. Fig. 3 shows the dependence of the concentration of certain metals on the samples compared to the TEC and PEC values, as well as the concentration of metals, investigated depending on the samples. When comparing the obtained values for the concentration of As with the TEC values $(9.79 \mathrm{mg} / \mathrm{kg})$, it is seen that in all samples this value is exceeded. The PEC value $(33.0 \mathrm{mg} / \mathrm{kg})$ is exceeded in samples $\mathrm{S} 2(161.12 \mathrm{mg} / \mathrm{kg}), \mathrm{S} 3$ $(132.55 \mathrm{mg} / \mathrm{kg})$ and $\mathrm{S} 6(53.87 \mathrm{mg} / \mathrm{kg})$ which are sources of contamination.

The TEC value for $\mathrm{Cd}$ is $0.99 \mathrm{mg} / \mathrm{kg}$. Only in sample $\mathrm{S} 1$ the concentration of Cd is lower, $0.49 \mathrm{mg} / \mathrm{kg}$. In all other sam-

Ecological risk and risk index (RI) classification

\begin{tabular}{|c|l|c|l|}
\hline Value of $E_{r}^{i}$ & \multicolumn{1}{|c|}{ Risk } & Value of $R I$ & \multicolumn{1}{|c|}{ Risk } \\
\hline$E_{r}^{i}<40$ & low potential ecological risk & $R I<150$ & low ecological risk for the lake/basin \\
\hline $40 \leq E_{r}^{i}<80$ & moderate potential ecological risk & $150 \leq R I<300$ & moderate ecological risk for the lake/basin \\
\hline $80 \leq E_{r}^{i}<160$ & considerable potential ecological risk & $300 \leq R I<600$ & considerable ecological risk for the lake/basin \\
\hline $160 \leq E_{r}^{i}<320$ & high potential ecological risk & $R I \geq 600$ & very high ecological risk for the lake/basin \\
\hline$E_{r}^{i} \geq 320$ & very high potential ecological risk & & \\
\hline
\end{tabular}

Heavy metal concentrations $(\mathrm{mg} / \mathrm{kg} \mathrm{dw}$ ) in sediment samples from rivers Sitnica

\begin{tabular}{|c|c|c|c|c|c|c|c|c|c|}
\hline Sample & $\mathrm{As}$ & $\mathrm{Cd}$ & $\mathrm{Co}$ & $\mathrm{Cr}$ & $\mathrm{Cu}$ & $\mathrm{Ni}$ & $\mathrm{Pb}$ & $\mathrm{Zn}$ & $\mathrm{Al}$ \\
\hline $\mathrm{S} 1$ & 16.87 & 0.49 & 16.75 & 92.43 & 23.12 & 119.82 & 109.42 & 138 & 8030 \\
\hline $\mathrm{S} 2$ & 161.12 & 3.68 & 12.63 & 23.42 & 67.67 & 48.12 & 1225.72 & 1752 & 6310 \\
\hline $\mathrm{S} 3$ & 132.55 & 28.76 & 13.82 & 85.78 & 87.21 & 103.54 & 1408.21 & 3258 & 7250 \\
\hline $\mathrm{S} 4$ & 24.75 & 28.45 & 11.24 & 74.87 & 28.61 & 101.64 & 243.57 & 8298 & 6490 \\
\hline S5 & 14.46 & 18.37 & 14.23 & 77.65 & 50.08 & 98.28 & 198.65 & 3234 & 10400 \\
\hline S6 & 53.87 & 34.14 & 12.65 & 73.87 & 52.24 & 118.12 & 326.74 & 6785 & 11800 \\
\hline TEC $^{\text {a }}$ & 9.79 & 0.99 & - & 43.4 & 31.6 & 22.7 & 35.8 & 121 & - \\
\hline PEC $^{\text {b }}$ & 33.0 & 4.98 & - & 111 & 149 & 48.6 & 128 & 459 & - \\
\hline
\end{tabular}

TEC ${ }^{a}$ - Threshold Effect Concentrations; $P E C^{b}$ - Probable Effect Concentrations 

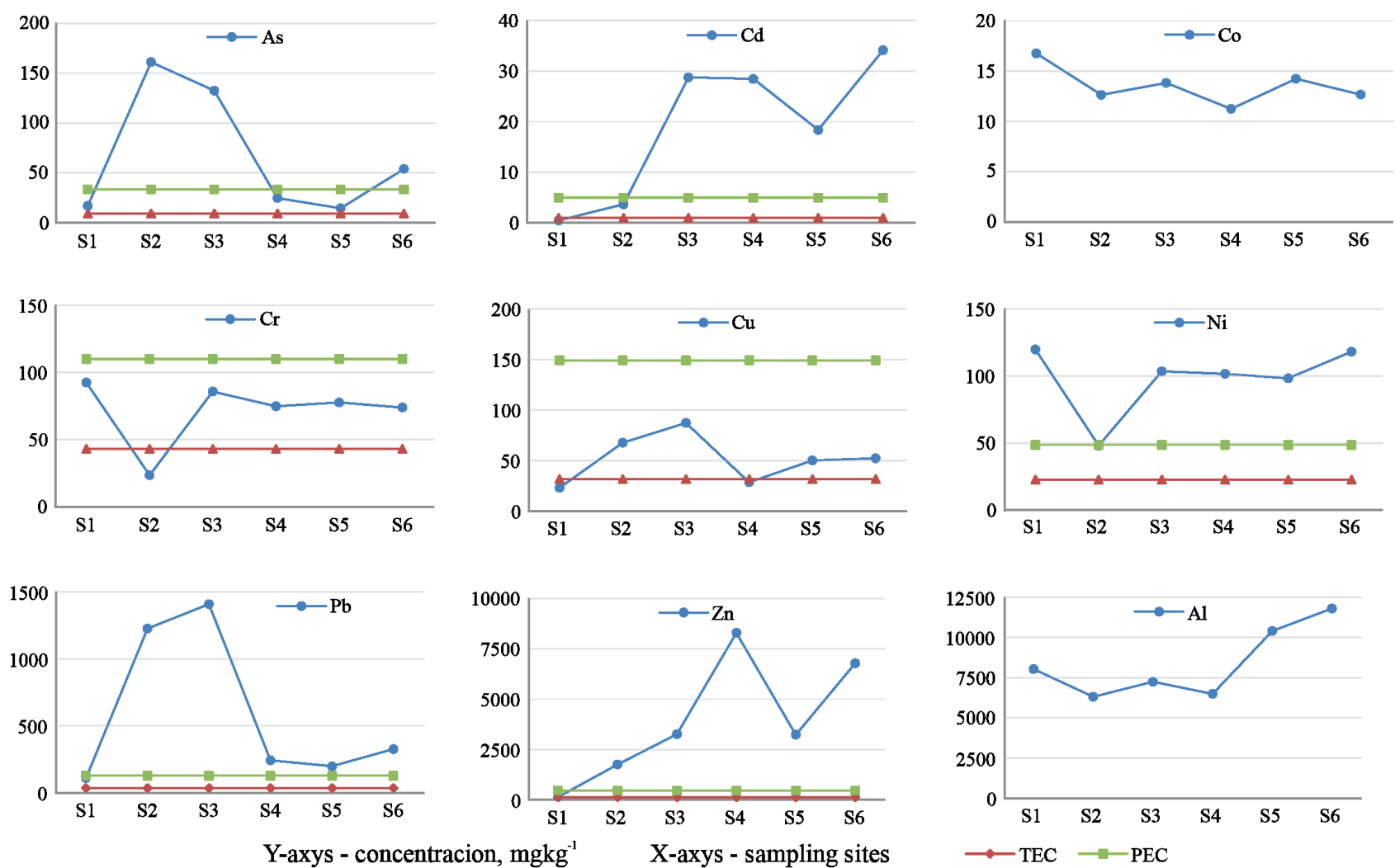

Fig. 3. Concentration according to sampling sites

ples, the concentration of $\mathrm{Cd}$ is higher. The PEC value $(4.98 \mathrm{mg} / \mathrm{kg})$ is exceeded in samples S3 $(28.76 \mathrm{mg} / \mathrm{kg}), \mathrm{S} 4$ $(28.37 \mathrm{mg} / \mathrm{kg})$, S5 $(18.37 \mathrm{mg} / \mathrm{kg})$ and $\mathrm{S} 6(34.14 \mathrm{mg} / \mathrm{kg})$. Therefore based on the concentration of $\mathrm{Cd}$ in these sampling sites, it is seen that it is a source of toxicity.

The PEC and TEC values for $\mathrm{Co}$ and $\mathrm{Al}$ are not found in the literature we have consulted. In $\mathrm{Cr}$, the TEC value $(43.4 \mathrm{mg} / \mathrm{kg})$ except for $\mathrm{S} 2(23.42 \mathrm{mg} / \mathrm{kg})$ in all samples is exceeded. The PEC value $(111 \mathrm{mg} / \mathrm{kg})$ is not exceeded in any sample. Values are from 73.87 to $92.43 \mathrm{mg} / \mathrm{kg}$ which is an above-average source of pollution. The TEC value for $\mathrm{Cu}$ is $31.6 \mathrm{mg} / \mathrm{kg}$. The lowest values are in S1 $(23.12 \mathrm{mg} / \mathrm{kg})$ and S4 $(28.61 \mathrm{mg} / \mathrm{kg})$, in all other samples the values are higher than $31.6 \mathrm{mg} / \mathrm{kg}$. Values range within $50.08-87.21 \mathrm{mg} / \mathrm{kg}$. The PEC value for $\mathrm{Cu}$ is $149 \mathrm{mg} / \mathrm{kg}$. In all samples the concentration of $\mathrm{Cu}$ is lower; however, based on the values obtained we are dealing with average contamination. The TEC value for $\mathrm{Ni}$ is $22.7 \mathrm{mg} / \mathrm{kg}$. It is characteristic that in all sampling sites the concentration of $\mathrm{Ni}$ is higher. Also the PEC value, $48.6 \mathrm{mg} / \mathrm{kg}$, is exceeded in all sampling sites. The values obtained are from 48.12 to $119.82 \mathrm{mg} / \mathrm{kg}$. Ni is also present in all samples as a source of contamination.

The TEC value for $\mathrm{Pb}$ is $35.8 \mathrm{mg} / \mathrm{kg}$. In all analyzed samples the $\mathrm{Pb}$ concentration is much higher than the value $35.8 \mathrm{mg} / \mathrm{kg}$ for TEC. Also the PEC value, $128 \mathrm{mg} / \mathrm{kg}$, is exceeded in all analyzed samples. Values are from 198.65 to $1408.21 \mathrm{mg} / \mathrm{kg}$, which is a source of pollution. In $\mathrm{Zn}$ the TEC value is $121 \mathrm{mg} / \mathrm{kg}$. The concentration of $\mathrm{Zn}$ in all samples exceeds this value $(121 \mathrm{mg} / \mathrm{kg})$. While the PEC value is $459 \mathrm{mg} / \mathrm{kg}$. Except for $\mathrm{S} 1$ $(138 \mathrm{mg} / \mathrm{kg})$, in all other sampling sites, the PEC value is exceeded. They are from 1752 to $8298 \mathrm{mg} / \mathrm{kg}$. From the obtained values it can be seen that $\mathrm{Zn}$ has a toxic effect on the environment.

Heavy metals indices. Geo-accumulation index. The calculated values of the Geo-accumulation index are presented in Table 7, while in Fig. 4 the dependence of the Geoaccumulation index from the sediment sampling sites in the Sitnica River is presented graphically. Based on the Muller (1979) classification, Table 2, S6 sampling site belongs to class 2 pollution, moderate contaminated. At S3 sampling site, we are dealing with class 3-pollution, i.e. pollution is moderate to strongly contaminate. At S2 sampling site, the pollution is class 4 respectively strongly contaminated.

According to the obtained values for the geo-accumulation index, Cd at sampling site $\mathrm{S} 1$ belongs to class 1 , uncontaminated. At S2 sampling site, Cd belongs to 4, strongly contaminated. In samples S3, S4, S5 the values of the geo-accumulation index are higher than 5, i.e. the pollution is ex-

Table 7

Geo-accumulation index for stream sediments

\begin{tabular}{|c|c|c|c|c|c|c|c|c|c|}
\hline Sample & $\mathrm{As}$ & $\mathrm{Cd}$ & $\mathrm{Co}$ & $\mathrm{Cr}$ & $\mathrm{Cu}$ & $\mathrm{Ni}$ & $\mathrm{Pb}$ & $\mathrm{Zn}$ & $\mathrm{Al}$ \\
\hline $\mathrm{S} 1$ & -0.224 & 0.122 & -0.766 & -0.546 & -1.545 & 0.232 & 1.867 & 0.0462 & 3.901 \\
\hline $\mathrm{S} 2$ & 3.047 & 3.032 & -1.174 & -2.527 & 0.0036 & -1.084 & 5.353 & 3.620 & 4.249 \\
\hline S3 & 2.765 & 5.998 & -1.044 & -0.654 & 0.369 & 0.0216 & 5.553 & 4.515 & 4.049 \\
\hline S4 & 0.344 & 5.982 & -1.342 & -0.850 & -1.238 & -0.005 & 3.021 & 5.864 & 4.209 \\
\hline S5 & -0.432 & 5.352 & -1.002 & -0.797 & -0.430 & -0.053 & 2.727 & 4.504 & 3.528 \\
\hline S6 & 1.466 & 6.246 & -1.171 & -0.870 & -0.369 & 0.211 & 3.445 & 5.573 & 3.346 \\
\hline
\end{tabular}




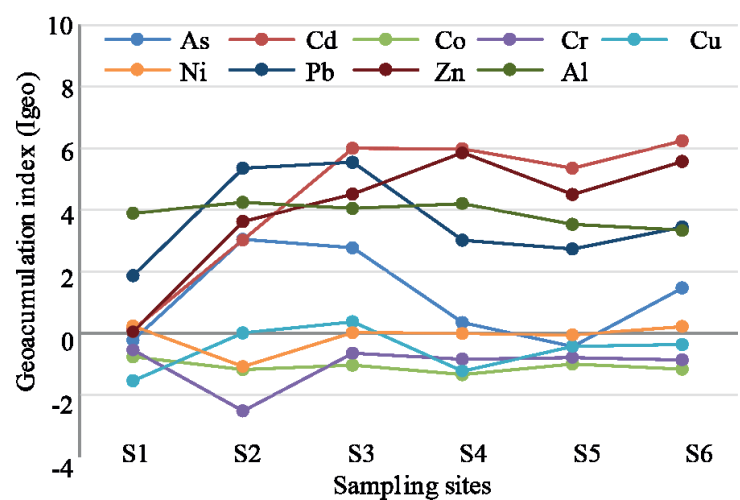

Fig. 4. Geo-accumulation Index of heavy metal in Sitnica river sediments

tremely contaminated as well as the $\mathrm{S} 6$ sample having a value higher than 6 . So the contamination is class 6 . The values of the geo-accumulation index show that we have no pollution with $\mathrm{Cr}$.

We have no or very little contamination in all sampling sites where $\mathrm{Co}, \mathrm{Cr}, \mathrm{Cu}$, and $\mathrm{Ni}$ have been investigated. Therefore, we are dealing with class 0 respectively 1 . As for $\mathrm{Pb}$ in sample S1, it belongs to class 2 pollution, moderate contaminated; in sample $\mathrm{S} 5$ it belongs to pollution class 3 , moderately to strongly contaminate. While at S4 and S5 sampling sites, the contaminants are class 4 , strongly contaminated. Samples S2 and $\mathrm{S} 3$ have values above 5 and belong to class 6 of pollution, extremely contaminated.

$\mathrm{Zn}$ in sample $\mathrm{S} 1$ belongs to class 1, uncontaminated pollution. At $\mathrm{S} 2$ sampling site, the pollution is class 4, strongly contaminated. S3 and S5 sampling sites enter grade 5, strongly to extremely contaminate. At S4 and S6 sampling sites, the pollution is strong to extremely contaminate.

$\mathrm{Al}$ at sampling sites $\mathrm{S} 1, \mathrm{~S} 5$, and S6 entered the $4^{\text {th }}$ class of pollution, strongly contaminated. While at sampling sites S2, $\mathrm{S} 3$, S4, it enters pollution class 5 , strongly to extremely contaminate.

The Contamination Factor. The obtained values for the Contamination Factor based on the Hakanson's classification indicate a high degree of sediment contamination. The obtained values are given in Table 9, while the graphical representation - in Fig. 5 Values for $\mathrm{As}, \mathrm{Pb}$ at all sampling sites indicate that we are dealing with a very high contamination factor.

Even $\mathrm{Cd}$ and $\mathrm{Zn}$ except for sampling site S1, in all other sampling sites, show enormously high contamination factor. In venom Sampling, Cd has the value 5 which has to do with the Considerable contamination factor.

$\mathrm{Zn}$ at sample $\mathrm{S} 1, \mathrm{Cr}$ at sample $\mathrm{S} 1, \mathrm{Cu}$ at sample $\mathrm{S} 2, \mathrm{~S} 4, \mathrm{~S} 5$, $\mathrm{S} 6$, and $\mathrm{Ni}$ in all samples indicate moderate contamination factor. $\mathrm{Cu}$ at sampling site S3 indicates a considerable contamination factor. Co at all sampling sites, $\mathrm{Cr}$ except for sampling site $\mathrm{S} 1$ and $\mathrm{Cu}$ at sampling site $\mathrm{S} 1$ indicate low contamination factor.

The values indicate a paramount anthropogenic impact on all sampling sites. The values for are given in Table 9, while the graphical presentation in Fig. 5. Except for sampling site 1 which belongs to a moderate degree of contamination, in all other sampling sites is an ultra-high degree of contamination.

Degree of contamination and modified degree of contamination. The results for the degree of contamination and modified degree of contamination are given in Table 8 and Fig. 6. The description of the modified degree of contamination $\left(m C_{d}\right)$ for sediments, Table 8 , shows that $\mathrm{S} 1$ has a moderate degree of contamination, S2 has extremely high degree of contamination, while all other sampling demonstrate ultra-high degree of contamination

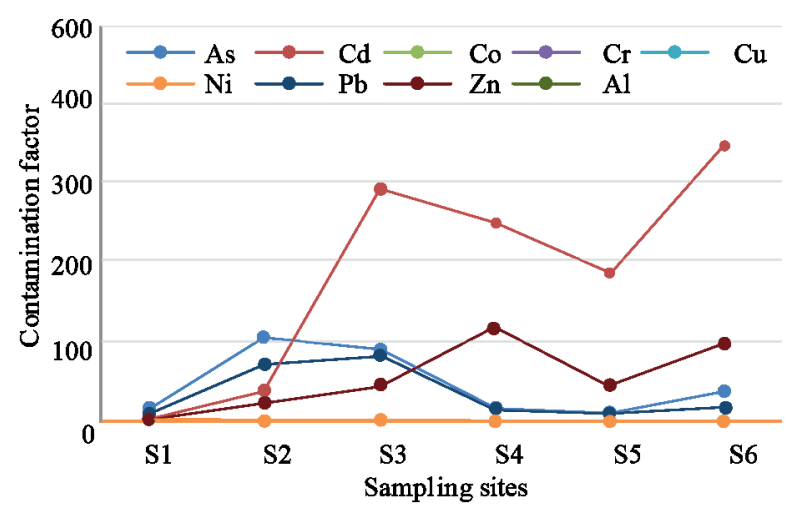

Fig. 5. Contamination factor of heavy metal of Sitnica river sediments

Enrichment factor (EF). In this study, the values of $E F$ are given in Table 10 while the graphic presentation is in Fig. 7. From the obtained results for As it can be seen that in the sampling site S5 (8.55) we are dealing with moderately severe en-

Table 8

$C_{d}, m C_{d}$ and pollution load index $(P L I)$ of Sitnica river sediments

\begin{tabular}{|c|c|c|c|}
\hline Samples & $C_{d}$ & $m C_{d}$ & $P L I$ \\
\hline $\mathrm{S} 1$ & 30.31 & 3.79 & 2.56 \\
\hline $\mathrm{S} 2$ & 246.53 & 30.81 & 6.73 \\
\hline $\mathrm{S} 3$ & 521.19 & 65.15 & 12.64 \\
\hline $\mathrm{S} 4$ & 402.17 & 50.27 & 7.54 \\
\hline $\mathrm{S} 5$ & 260.28 & 32.53 & 6.51 \\
\hline $\mathrm{S} 6$ & 505.43 & 63.18 & 9.76 \\
\hline
\end{tabular}

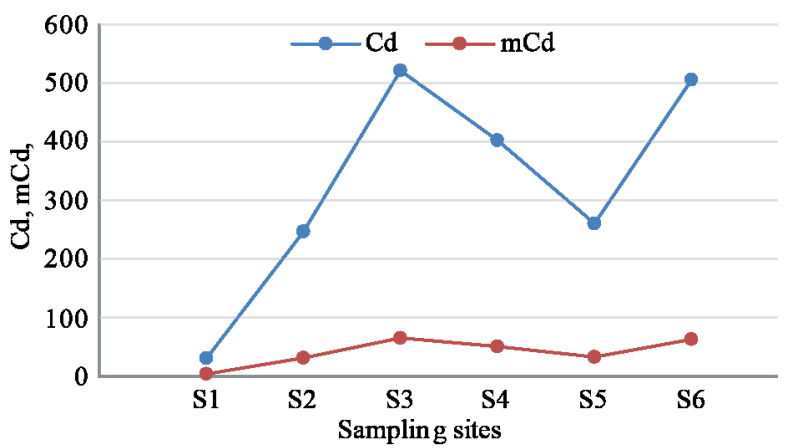

Fig. 6. Cd, and pollution load index (PLI) in Sitnica river sediments

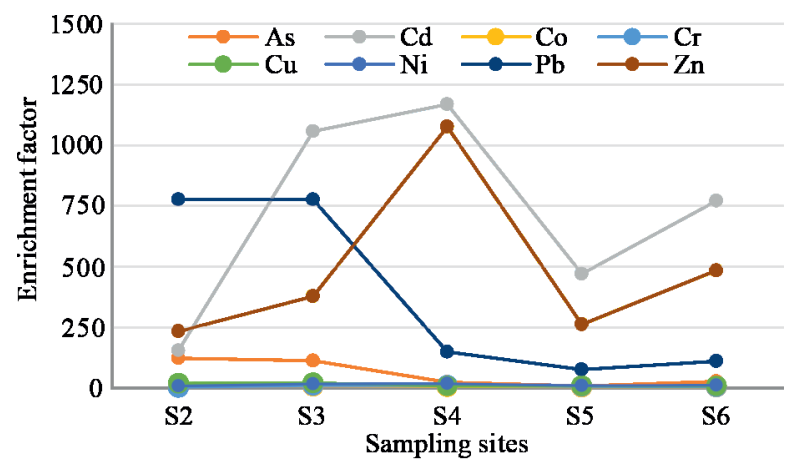

Fig. 7. Enrichment factor in stream sediments 
Contamination Factor

\begin{tabular}{|c|c|c|c|c|c|c|c|c|}
\hline \multicolumn{9}{|c|}{$C_{f}^{i}$ values } \\
\hline Sample & As & $\mathrm{Cd}$ & Co & $\mathrm{Cr}$ & $\mathrm{Cu}$ & $\mathrm{Ni}$ & $\mathrm{Pb}$ & $\mathrm{Zn}$ \\
\hline S1 & 11.24 & 5.00 & 0.98 & 1.08 & 0.92 & 2.72 & 6.43 & 1.94 \\
\hline S2 & 107.41 & 37.55 & 0.74 & 0.27 & 2.70 & 1.09 & 72.10 & 24.67 \\
\hline S3 & 88.36 & 293.47 & 0.81 & 1.00 & 3.49 & 2.35 & 82.83 & 45.88 \\
\hline $\mathrm{S} 4$ & 16.50 & 249.49 & 0.66 & 0.88 & 1.14 & 2.31 & 14.32 & 116.87 \\
\hline S5 & 9.64 & 187.44 & 0.83 & 0.91 & 2.00 & 2.23 & 11.68 & 45.55 \\
\hline S6 & 35.91 & 348.36 & 0.74 & 0.87 & 2.09 & 2.68 & 19.22 & 95.56 \\
\hline
\end{tabular}

Table 10

Enrichment Factor in stream sediments

\begin{tabular}{|c|c|c|c|c|c|c|c|c|}
\hline Sample & As & $\mathrm{Cd}$ & $\mathrm{Co}$ & $\mathrm{Cr}$ & $\mathrm{Cu}$ & $\mathrm{Ni}$ & $\mathrm{Pb}$ & $\mathrm{Zn}$ \\
\hline $\mathrm{S} 1$ & 12.92 & 16.27 & 8.78 & 10.23 & 5.12 & 17.55 & 54.50 & 14.40 \\
\hline $\mathrm{S} 2$ & 123.47 & 155.46 & 8.42 & 3.30 & 19.06 & 8.97 & 777.00 & 233.81 \\
\hline $\mathrm{S} 3$ & 112.51 & 1057.84 & 8.02 & 10.51 & 21.38 & 16.80 & 776.94 & 378.42 \\
\hline S4 & 23.46 & 1168.97 & 7.29 & 10.25 & 7.83 & 18.42 & 150.12 & 1076.64 \\
\hline S5 & 8.55 & 471.02 & 5.76 & 6.63 & 8.56 & 11.11 & 76.40 & 261.70 \\
\hline S6 & 28.09 & 771.25 & 4.51 & 5.56 & 7.87 & 11.77 & 110.75 & 484.21 \\
\hline
\end{tabular}

richment. In samples S1 (12.92) and S4 (23.46), EF is in the category with severe enrichment, in sample S6 (28.09) - with very severe enrichment. While at sampling sites S2 (1213.47) and S3 (112.51), there is extremely severe enrichment.

At $C d$ at sampling site $\mathrm{S} 1$ (16.27), EF is in the severe enrichment category, while at all other sampling sites it is extremely severe enrichment. The value of EF is from 155.46 to 1168.97. $E F$ for Co at all sampling sites has lower values, from 4.51 (S6) to 8.78 (S1), which belongs to the category of moderate enrichment and moderately severe enrichment. $E F$ values for $\mathrm{Cr}$ are from 3.30 (S2) to -10.51 (S3), which belongs to the category of moderate enrichment, respectively severe enrichment. The $E F$ values for $\mathrm{Cu}$ are from 5.12 (S1) to 21.38 (S3), and belong to the category of moderately severe enrichment, respectively, the category of severe enrichment. In $\mathrm{Ni}$, the $E F$ values range from 8.97 (S2) to 18.42 (S4), belonging to the category of severe enrichment and severe enrichment.

High $E F$ values were obtained in all samples where $\mathrm{Pb}$ was investigated. $E F$ values are from 54.50 (S1) to 777.00 (S2). Thus, we have exceedingly severe enrichment. High values for $E F$ are also obtained for $\mathrm{Zn}$. The values are from 14.40 (S1), severe enrichment, to 1076.64 (S4), extremely severe enrichment.

The potential ecological risk factor. The values for the potential ecological risk factor are shown in Table 11. The assessment of the potential ecological risk factor for our measure- ments is based on the classification for Ecological risk, Table 11. The lowest value for As is 96.4 (S5) and the highest 1074.1 (S2), which presents a very high potential ecological risk. $C_{d}$ with the lowest value $150(\mathrm{~S} 1)$ and the highest 10450.8 (S6) presents a very high potential ecological risk. Values for Co are from 3.3 (S4) to 4.9 (S1), which represents low potential ecological risk. Values for $\mathrm{Cr}$ are from 0.54 (S2) to 2.16 (S1), which poses a low potential ecological risk. Values for NI are from $5.45(\mathrm{~S} 2)$ to $13.6(\mathrm{~S} 1)$, which represents low potential ecological risk. $\mathrm{Pb}$ values are in the range of 32.15 (S1) to 414.15 , which on average represents high potential ecological risk. Values for $\mathrm{Zn}$ depending on the sampling are from 1.94 (S1) to 116.87 (S4). As an average value, it poses a moderate potential ecological risk.

The potential ecological risk index (RI). The values obtained for the potential ecological risk index are given in Table 11. Based on the values for classification for the ecological risk index $(R I)$ given in Table 11 and Fig. 8, except for S1 which presents a considerable ecological risk, all sampling points indicate very high ecological risk.

Pollution Load Index (PLI). The calculated pollution load index $(P L I)$ values of metals in sediment are summarized in Table 8 and Fig. 9; they were ranged from 2.56 to 12.64, confirming that the sediment of the studied river was heavily contaminated $(P L I>1)$.

Table 11

The potential ecological risk factor in stream sediments

\begin{tabular}{|c|c|c|c|c|c|c|c|c|c|}
\hline \multirow{2}{*}{ Sample } & \multicolumn{8}{|c|}{$E_{r}^{i}$} & \multirow{2}{*}{$R I$} \\
\hline & As & $\mathrm{Cd}$ & Co & $\mathrm{Cr}$ & $\mathrm{Cu}$ & $\mathrm{Ni}$ & $\mathrm{Pb}$ & $\mathrm{Zn}$ & \\
\hline S1 & 112.4 & 150 & 4.9 & 2.16 & 4.6 & 13.6 & 32.15 & 1.94 & 321.45 \\
\hline S2 & 1074.1 & 1126.5 & 3.7 & 0.54 & 13.5 & 5.45 & 360.5 & 24.67 & 2608.96 \\
\hline S3 & 883.6 & 8804.1 & 4.05 & 2.00 & 17.45 & 11.75 & 414.15 & 45.88 & 10182.98 \\
\hline S4 & 165.0 & 7484.7 & 3.3 & 1.76 & 5.7 & 11.55 & 71.6 & 116.87 & 7860.48 \\
\hline S5 & 96.4 & 5623.2 & 4.15 & 1.82 & 10.0 & 11.15 & 58.4 & 45.55 & 5850.67 \\
\hline S6 & 359.1 & 10450.8 & 3.75 & 1.74 & 10.45 & 13.4 & 96.1 & 95.56 & 11030.1 \\
\hline
\end{tabular}




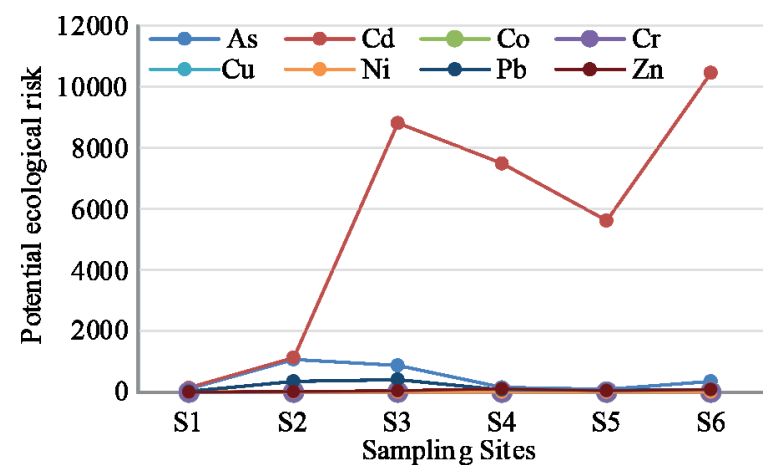

Fig. 8. Potential ecological risk in Sitnica river sediments

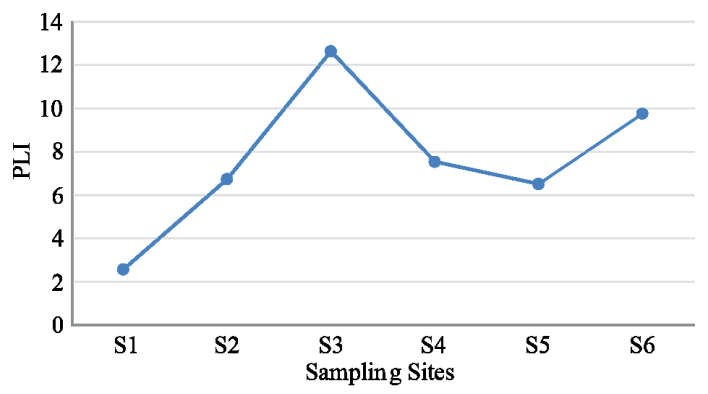

Fig. 9. Pollution Load Index in Sitnica river sediments

Conclusion. In the research on determination of heavy metals in the sediment of the river Sitnica and their ecological impact, pollution indicators are used by comparing the values obtained with those allowed. The geo-accumulation index, the contamination factor, the degree of contamination and modified degree of contamination, the enrichment factor, the potential ecological risk index, the potential ecological risk index, and the pollution load index were used, and from their high values, we conclude that we deal with very high pollution. The average values of Igeo revealed the following ranking of intensity of heavy metal contamination of the Sitnica river sediments: $\mathrm{Cd}>\mathrm{Zn}>\mathrm{Al}>\mathrm{Pb}>\mathrm{As}>\mathrm{Ni}>\mathrm{Cu}>\mathrm{Cr}>\mathrm{Co}$. The elevated presence of heavy metals as contaminants in the Sitnica River sediment is a concern in aquatic ecosystems. Sources of pollution are industrial landfills that due to erosion composition of these landfills can be discharged into the river Sitnica. Therefore, to protect against further pollution, it is required to repair these landfills and monitor them.

\section{References.}

1. Kadriu, S., Sadiku, M., Kelmendi, M., \& Sadriu, E. (2020). Studying the heavy metals concentration in discharged water from the Trepça Mine and flotation, Kosovo. Mining of Mineral Deposits, 14(4), 4752. https://doi.org/10.33271/mining 14.04.047.

2. Ibishi, G., Yavuz, M., \& Genis, M. (2020). Underground mining method assessment using decision-making techniques in a fuzzy environment: case study, Trepça mine, Kosovo. Mining of Mineral Deposits, 14(3), 134-140. https://doi.org/10.33271/mining14.03.134.

3. Malanchuk, Z., Malanchuk, Y., Korniyenko, V., \& Ignatyuk, I. (2017). Examining features of the process of heavy metals distribution in technogenic placers at hydraulic mining. Eastern-European Journal of Enterprise Technologies, 1(10(85)), 45-51. https://doi. org/10.15587/1729-4061.2017.92638.

4. Aben, E. K., Rustemov, S.T., Bakhmagambetova, G. B., \& Akhmetkhanov, D. (2019). Enhancement of metal recovery by activation of leaching solution. Mining Informational and Analytical Bulletin, 12, 169-179. https://doi.org/10.25018/0236-1493-2019-12-0-169-179. 5. Sadiku, M., Kadriu, S., Kelmendi, M., \& Latifi, L. (2021). Impact of Artana mine on heavy metal pollution of the Marec river in Kosovo. Mining of Mineral Deposits, 15(2), 18-24. https://doi.org/10.33271/ mining 15.02 .018

6. Sadiku, M. (2011). The influence of the tailing in the Industrial Park in Mitrovica on polluting of Sitnica River. Energy, Environment, Devices, Systems, Communications, Computers, 247-251.
7. Guan, J., Wang, J., Pan, H., Yang, C., Qu, J., Lu, N., \& Yuan, X. (2018). Heavy metals in Yinma River sediment in a major Phaeozems zone, Northeast China: Distribution, chemical fraction, contamination assessment and source apportionment. Scientific Reports, 8(1), 1-11. https://doi.org/10.1038/s41598-018-30197-Z.

8. Hsu, L. C., Huang, C. Y., Chuang, Y. H., Chen, H. W., Chan, Y. T., Teah, H.Y., \& Tzou, Y. M. (2016). Accumulation of heavy metals and trace elements in fluvial sediments received effluents from traditional and semiconductor industries. Scientific Reports, 6(1), 1-12. https:// doi.org/10.1038/srep34250.

9. Shen, F., Mao, L., Sun, R., Du, J., Tan, Z., \& Ding, M. (2019). Contamination Evaluation and Source Identification of Heavy Metals in the Sediments from the Lishui River Watershed, Southern China. International Journal of Environmental Research and Public Health, 16(3), 336. https://doi.org/10.3390/ijerph16030336.

10. Suresh, G., Ramasamy, V., Meenakshisundaram, V., Venkatachalapathy, R., \& Ponnusamy, V. (2011). Influence of mineralogical and heavy metal composition on natural radionuclide concentrations in the river sediments. Applied Radiation and Isotopes, 69(10), 1466-1474. https://doi.org/10.1016/j.apradiso.2011.05.020.

11. El-Sayed, S. A., Moussa, E. M. M., \& El-Sabagh, M. E. I. (2015) Evaluation of heavy metal content in Qaroun Lake, El-Fayoum, Egypt. Part I: Bottom sediments. Journal of Radiation Research and Applied Sciences, 8(3), 276-285. https://doi.org/10.1016/j.jrras.2015.02.011.

12. Ozkan, E. Y., \& Buyukisik, B. (2012). Geochemical and Statistical Approach for Assessing Heavy Metal Accumulation in the Southern Black Sea Sediments. Ekoloji, 21(83), 11-24. https://doi.org/10.5053/ ekoloji.2012.832.

13. Salati, S., \& Moore, F. (2010). Assessment of heavy metal concentration in the Khoshk River water and sediment, Shiraz, Southwest Iran. Environ Monit Assess, 164, 677-689. https://doi.org/10.1007/ s10661-009-0920-y.

14. ZareZadeh, R., Rezaee, P., Lak, R., Masoodi, M., \& Ghorbani, M. (2017). Distribution and accumulation of heavy metals in sediments of the northern part of mangrove in Hara Biosphere Reserve, Qeshm Island (Persian Gulf). Soil and Water Research, 12(2), 86-95. https://doi.org/10.17221/16/2016-SWR.

15. Zahra, A., Hashmi, M.Z., Malik, R. N., \& Ahmed, Z. (2014). Enrichment and geo-accumulation of heavy metals and risk assessment of sediments of the Kurang Nallah-Feeding tributary of the Rawal LakeReservoir, Pakistan. Science of the Total Environment, 470471(2014), 925-933. https://doi.org/10.1016/j.scitotenv.2013.10.017.

16. Rahman, M.A., \& Ishiga, H. (2011). Trace metal concentrations in tidal flat coastal sediments, Yamaguchi Prefecture, southwest Japan. Environmental Monitoring and Assessment, 184(9), 5755-5771. https://doi.org/10.1007/s10661-011-2379-x.

17. Kumar, A., Ramanathan, A. L., Prabha, S., Ranjan, R. K., Ranjan, S., \& Singh, G. (2011). Metal speciation studies in the aquifer sediments of Semria Ojhapatti, Bhojpur District, Bihar. Environmental Monitoring and Assessment, 184(5), 3027-3042. https://doi. org/10.1007/s10661-011-2168-6.

18. Islam, M. S., Ahmed, M. K., Raknuzzaman, M., Habibullah AlMamun, M., \& Islam, M. K. (2015). Heavy metal pollution in surface water and sediment: A preliminary assessment of an urban river in a developing country. Ecological Indicators, 48, 282-291. https://doi. org/10.1016/j.ecolind.2014.08.016.

19. Mandeng, E. P. B., Bidjeck, L. M. B., Bessa, A. Z. E., Ntomb, Y. D., Wadjou, J. W., Doumo, E. P. E., \& Dieudonné, L. B. (2019). Contamination and risk assessment of heavy metals, and uranium of sediments in two watersheds in Abiete-Toko gold district, Southern Cameroon. Heliyon, 5(10), e02591. https://doi.org/10.1016/i.helivon.2019.e02591. 20. Özkan, E. Y. (2012). A new assessment of heavy metal contaminations in an eutrophicated bay (Inner Izmir Bay, Turkey). Turkish Journal of Fisheries and Aquatic Sciences, 12(1), 135-147.

21. Singh, H., Pandey, R., Singh, S. K., \& Shukla, D. N. (2017). Assessment of heavy metal contamination in the sediment of the River Ghaghara, a major tributary of the River Ganga in Northern India. Applied Water Science, 7(7), 4133-4149. https://doi.org/10.1007/s13201-017-0572-y.

22. Ahamad, M. I., Song, J., Sun, H., Wang, X., Mehmood, M. S., Sajid, M., \& Khan, A.J. (2020). Contamination Level, Ecological Risk, and Source Identification of Heavy Metals in the Hyporheic Zone of the Weihe River, China. International Journal of Environmental Research and Public Health, 17(3), 1070. https://doi.org/10.3390/ijerph17031070. 23. Doabi, S. A., Karami, M., \& Afyuni, M. (2019). Heavy metal pollution assessment in agricultural soils of Kermanshah province, Iran. Environmental Earth Sciences, 78(3), 70-78. https://doi.org/10.1007/ s12665-019-8093-7. 
24. Al-Mur, B.A., Quicksall, A. N., \& Al-Ansari, A. M.A. (2017). Spatial and temporal distribution of heavy metals in coastal core sediments from the Red Sea, Saudi Arabia. Oceanologia, 59(3), 262-270. https://doi.org/10.1016/j.oceano.2017.03.003.

25. Huang, Z., Liu, C., Zhao, X., Dong, J., \& Zheng, B. (2020). Risk assessment of heavy metals in the surface sediment at the drinking water source of the Xiangjiang River in South China. Environmental Sciences Europe, 32(1). https://doi.org/10.1186/s12302-020-00305-w. 26. Pejman, A., Nabi Bidhendi, G., Ardestani, M., Saeedi, M., \& Baghvand, A. (2015). A new index for assessing heavy metals contamination in sediments: A case study. Ecological Indicators, 58, 365-373. https://doi.org/10.1016/i.ecolind.2015.06.012.

27. Delshab, H., Farshchi, P., \& Keshavarzi, B. (2017). Geochemical distribution, fractionation and contamination assessment of heavy metals in marine sediments of the Asaluyeh port, Persian Gulf. $\mathrm{Ma}$ rine Pollution Bulletin, 115(1-2), 401-411. https://doi.org/10.1016/j. marpolbul.2016.11.033.

28. Ahamad, M.I., Song, J., Sun, H., Wang, X., Mehmood, M. S., Sajid, M., \& Khan, A.J. (2020). Contamination Level, Ecological Risk, and Source Identification of Heavy Metals in the Hyporheic Zone of the Weihe River, China. International Journal of Environmental Research and Public Health, 17(3), 1070. https://doi.org/10.3390/ijerph17031070. 29. Kowalska, J. B., Mazurek, R., Gasiorek, M., \& Zaleski, T. (2018). Pollution indices as useful tools for the comprehensive evaluation of the degree of soil contamination-A review. Environmental Geochemistry and Health, 40(6), 2395-2420. https://doi.org/10.1007/s10653-018-0106-z. 30. Ke, X., Gui, S., Huang, H., Zhang, H., Wang, C., \& Guo, W. (2017). Ecological risk assessment and source identification for heavy metals in surface sediment from the Liaohe River protected area, China. Chemosphere, 175, 473-481. https://doi.org/10.1016/j.chemosphere.2017.02.029.

\section{Оцінка забруднення відкладень у річці Ситниця важкими металами на основі показників забруднення}

\section{Мілаім Садіку, Менсур Кельменді, Садія Кадріу}

Факультет харчових технологій, Університет Митровиці «Іса Болетіні», м. Митровиця, Республіка Косово, е-mail: milaim.sadiku@umib.net
Мета. Показати вплив полігону індустріального парку Митровиці на забруднення річки Ситниця за допомогою аналізу донних відкладень. Із цією метою для оцінки рівня забруднення та екологічного впливу використовувалися індикатори забруднення: індекс геонакопичення, коефіцієнт забруднення, ступінь забруднення й модифікований ступінь забруднення, коефіцієнт збагачення, показник потенційного екологічного ризику, індекс концентрації забруднення.

Методика. Для відбору проб донних наносів використовувався стандартний метод ISO 5667-15:2009. У той же час стандартний метод ISO 11885:2007 використовувався для визначення вибраних елементів за допомогою оптико-емісійної спектрометрії з індуктивно зв'язаною плазмою (ICP-OES). У цьому розрахунку показників забруднення використовувалися аналітичні методи.

Результати. 3 отриманих результатів можна дійти невтішного висновку, що концентрації важких металів у донних відкладеннях річки Ситниця перевищують допустимі значення. За нашими оцінками, вплив полігону на забруднення річки Ситниця є незаперечним.

Наукова новизна. У статті представлені нові дані щодо впливу полігону індустріального парку Митровиці на забруднення річки Ситниця та, відповідно, на іiі екологічний стан. Висновки грунтуються на результатах аналізу проб і їх порівнянні $з$ допустимими значеннями для відкладень. Забруднення також впливає на харчовий ланцюжок, оскільки вода цієї річки використовується для зрошення садів, а також у річці ведеться лов риби.

Практична значимість. Слід взяти до уваги, що зміст і проблематика, порушені в цій статті, є актуальними та становлять значний інтерес для тих, хто займається цим питанням.

Ключові слова: важкі метали, індикатори забруднення, річка Ситниия, забруднення відкладень

The manuscript was submitted 06.02.21. 